\title{
Students' perception of service quality and its impact on their satisfaction in Amhara Region, Ethiopia
}

\author{
Demeke Lakew Workie $^{1 *}$, Haile Mekonnen Fenta ${ }^{1}$ and Essey Kebede Muluneh ${ }^{1}$ \\ ${ }^{1}$ Bahir Dar University, Science College, Statistics Department
}

\begin{abstract}
This paper was aimed to assess the impact of service quality of higher education institutions on students' satisfaction in Amhara region, Ethiopia. A cross-sectional survey was conducted among undergraduate students of government universities in the Amhara region who graduated in the academic year of 2014/15. A total of 552 students were selected for the study using multistage sampling technique. Cronbach's alpha was used to check the reliability of the questionnaire used for data collection. Chi-square test was used to test the association between students' satisfaction and service quality dimensions. Ordinal logistic regression analysis was used to examine the effects of service quality dimensions on students' satisfaction. The results showed that reliability, responsiveness and empathy have a significant impact on students' satisfaction while students' university, tangibility and assurance have no significant impact on students' satisfaction. The findings of the study revealed that students' satisfaction was much better than what was expected at their university. The results of the Chi-square test revealed a significant association between service quality dimensions and students' satisfaction. The ordinal logistic regression analysis revealed that reliability, responsiveness and empathy are significantly related with students' satisfaction and students who felt that the reliability, the responsiveness and the empathy. The quality of teaching methodologies, tasks with a friendly attitude of teaching, and the quality of learning environment were the key factors affecting the academic environment of an institution. The physical appearance of educational institution is not a matter instead the essence of students' satisfaction lies in the quality of teaching and learning, experienced faculty, knowledgeable and liberality teachers. Universities are recommended to develop strict quality control and screening mechanisms while recruiting teachers.
\end{abstract}

Key words: Higher Education Institution, Service Quality, Students' Satisfaction, Ordinal Logistic Regression, Ethiopia.

DOI: http://dx.doi.org/10.4314/ejst.v10i2.2

\section{INTRODUCTION}

In today's competitive academic environment where students have many options available to them, factors that enable education institutions to attract and retain students should be seriously studied. Higher education institutions which want to gain competitive edge in future may need to begin searching for effective and creative ways to attract, retain and foster stronger relationship with students. Therefore, it is necessary to invest in quality system and tools for improvement. In this competitive market, satisfaction with services may make the differences (Parasuraman et al., 1996). Higher learning institutions are also considering this with the objective to satisfy students. Satisfying admitted students and trying to meet the needs of this ever-increasing number of students as well as the service quality they are demanding at this level of education, are important for the institutions' existence (DeShields et al., 2005).

*Corresponding author: demay_gu06@yahoo.com

(C) This is an Open Access article distributed under the terms of the Creative Commons Attribution License (http://creativecommons.org/licenses/CC BY4.0). 
Surveys on satisfaction provide colleges and universities with real pictures of the key issues perceived by their students. Consequently, the satisfaction results from the surveys have been used as feedback information to help college administrators and faculty to enhance the quality of programs and services. Various researchers have studied service quality of academic institutions from students' perspective using SERVQUAL model given by Parasurman et al. (1988) which contains five dimensions of quality i.e. Assurance, Responsiveness, Reliability, Tangibles and Empathy. These dimensions are applied in education sector as well as in various set ups. SERVQUAL model is analyzed and modified by some authors. For instance, the SERVPERF model (Cronin and Taylor, 1994); Graphic analysis for results processing (Murray, 2001); Descriptive Statistics (mean, standard deviation) and test statistics (Person's correlation, ANOVA and multiple regression analysis techniques (Barnes, 2005; Hair et al., 2006). The conceptual framework below explains the underlying process, which is applied to guide this study. The SERVQUAL model is suitable for measuring service quality and students' satisfaction in higher institutions offering services using the service quality dimensions which are modified. This is because we cannot use a generic SERVQUAL model in this context and will not provide a good measure of students' satisfaction.
Service quality is noted commonly an important prerequisite to establish and sustain satisfying relationships with customers and is one of the most important research topics on a large scale in services (Zeithaml, 2000; Gallifa and Batalle, 2010). Consumers are concerned not with how a service is delivered but only with the quality of output they receive. Quality perceptions of universities influence student's attitude toward the service. High levels of quality of service occur when the customer (student) perceives that the service provider exceeded his or her expectations. Student satisfaction with a service is able to create long term benefits for the university including positive word-of-mouth (Anderson et al., 1994).

Ordinal logistic regression model is appropriate for modeling responses that naturally have ordered scales. Little research on students' satisfaction in higher educational institutions has however been reported taking the ordinal nature of the response variable, satisfaction. This study therefore used ordinal logistic regression model to determine the impact of service quality dimensions (Tangibility, Reliability, Responsiveness, Assurance and Empathy) and demographic variables on students' satisfaction in Amhara region universities. Based on the statement of the problem presented above the study attempts to answer the following research questions:

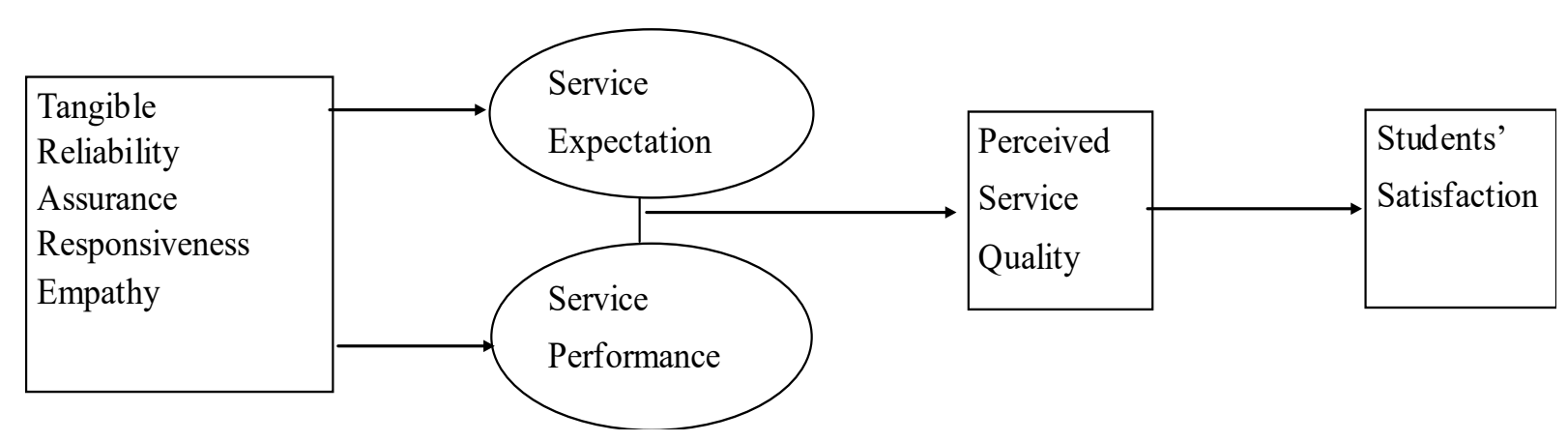

Modified SERVQUAL model Conceptual Framework 
1. What is the impact of service quality dimensions on students' satisfaction in Amhara region higher education institutions?

2. Which service quality dimensions contribute most to the students' satisfaction?

\section{METHODOLOGY}

\section{Research Design}

The focus of this study was to examine the impact of service quality dimensions on students' satisfaction in Amhara region. In this region, there are seven governmental universities. A cross-sectional survey was conducted among undergraduate students of Amhara region universities who graduated in the academic year 2014/15. The sources of data for this study were Bahir Dar University, Debre Berhan University and University of Gondar. The sampling frame consisted of 10105 undergraduate students who graduated in the academic year 2014/15.

\section{Sample and Sampling Techniques}

All Ethiopian higher educational institutions have similar functionality, code of conduct and appropriate curriculum governed by the ministry of education of Ethiopia (MOE). The similarities of working conditions, educational courses and work climate thus constitute a homogenous population. As a result, multistage sampling method, with the proportion of students' satisfaction equal to 0.643 (Demeke Lakew, 2014) and margin of error 0.04 at a response rate of $90 \%(495 / 552)$, was used for selecting a representative sample of undergraduate students in 2014/15 academic year. As the number of students in the academic year of 2014/15 in Ethiopian higher education was more than 10,000, an initial estimate sample size, $n_{0}$, was considered as adequate sample size, $n$ (Cochran, 1977). These assumptions led to a sample size of 552 students from three universities in Amhara region: Bahir Dar University, Debre Birhan University and University of Gondar.

\section{Instruments of Data Collection}

The data was collected using structured questionnaire consisting of three sections: Demographic factors, Measurement of Service Quality in Higher Education and Measurement of Students' Satisfaction. The dependent (response) variable in this study was students' satisfaction. Kotler and Clarke (1987) define satisfaction as a state felt by a person who has experienced performance or an outcome that fulfill his or her expectation. Hence in this study, students' satisfaction was defined as 'a state felt by students that fulfill their expectation from their universities'. And the independent variables were service quality dimensions (Tangibility, Reliability, Responsiveness, Assurance, and Empathy) in higher education. The construct of quality as conceptualized in the services literature is based on the perceived quality. Perceived quality is defined as the consumer's judgment about an entity's overall experience or superiority (Zeithaml, 1987; Zammuto et al., 1996). Similarly, Parasuraman et al. (1990) also concluded that consumer perceptions of service quality result from comparing expectations prior to receiving the service, and their actual experience of the service. Hence in this study service quality is defined as 'the quality of a service that a student experiences after getting exposed of a certain service offered by their university'. In this research, the initial 22 items of SERVQUAL model were modified and additional items were included to measure the perceived service quality and students' satisfaction in higher institutions. The measurements of students' satisfaction contain 14 items and used 
the five point Likert scale from 1= very dissatisfied to $5=$ very satisfied. The measurements of service quality were based on the five dimensions of service quality (tangibility, assurance, reliability, responsiveness and empathy) contains 14, 6, 14, 7 and 4 items (totaling 45 items) respectively and used the three point Likert scale with 1 poor, 2 fair and 3 good.

\section{Reliability of the Instruments}

For the internal consistency and reliability, researchers measured the Crobach's alpha, which is a method of estimating internal reliability. The reliability coefficients of all service quality dimensions and students' satisfaction were tested and found to be greater than 0.75 and those values over 0.75 were considered as good (Sekaran, 1992). The Cronbach's alpha coefficients for tangibility, assurance, reliability, responsiveness, and empathy in this study were $0.847,0.836,0.871$, 0.795 and 0.751 respectively. This shows that the coefficients of the Cronbach's alpha exceeded the threshold of 0.75 for all measurements indicating that the questionnaire used was consistent and reliable.

\section{Data Analysis Methods}

This empirical study tried to determine the impact of service quality on students' satisfaction in three government owned universities: Bahir Dar University, Debre Berhan University and University of Gondar in Amhara Region, Ethiopia. Descriptive statistics, chi-square and ordinal logistic regression techniques were used to examine the data. Descriptive statistics and chisquare test were used to investigate the degree of students' satisfaction and to investigate the association between service quality dimensions. The chi-square test for independence, also called Pearson's chi-square test or the chi-square test of association, was used to discover if there is an association between two categorical variables. The variables students' satisfaction and the five service quality dimensions (Tangibility, Reliability, Responsiveness, Assurance and Empathy) used in this study are all categorical variables. Pearson Chi-Square provides information about the existence of relationship between categorical variables, but not about the magnitude of the relationship. As a result, a different index must be used to measure the strength of the relationship between the categorical variables. Such index is Phi Coefficient and Cramer's V. Phi coefficient is the measure of the strength of the association between categorical variables and Cramer's V is a rescaling of phi. Ordinal logistic regression model was used to examine the impact of service quality dimensions on students' satisfaction and that contribute most towards students' satisfaction. The responses of students were coded, entered and analysed using Statistical package for social science (SPSS) version 21.

\section{Ordinal Logistic Regression Model}

The ordinal logistic regression model is one among many models subsumed under the rubric of generalized linear models for ordinal data. In ordinal logistic regression, the event of interest is observing a particular score or less. All of the odds are of the form:

$\theta_{j}=\frac{\operatorname{Prob}(\text { score } \leq j)}{\operatorname{Prob}(\text { score }>j)}=\frac{\operatorname{Prob}(\text { score } \leq \mathrm{j})}{[1-\operatorname{Prob}(\text { score } \leq j)]}=e^{\alpha_{j}+\beta X}$

If multiple explanatory variables are applied to the ordinal regression model, $\beta \mathrm{X}$ is replaced by the linear combination of $\beta \mathrm{o}+\beta_{1} X_{1}+\beta_{2} X_{2}+\beta_{3} X_{3}+\ldots+\beta_{k} X_{k}$ and the logit is 
$\operatorname{logit}\left[\mathrm{p}(\mathrm{y} \leq \mathrm{j} / \mathrm{x}]=\alpha_{\mathrm{j}}+\beta_{1} \mathrm{X}_{1}+\beta_{2} \mathrm{X}_{2}+\beta_{3} \mathrm{X}_{3}+\cdots+\beta_{\mathrm{k}} \mathrm{X}_{\mathrm{k}}\right.$

The threshold $\left(\boldsymbol{\alpha}_{\boldsymbol{j}}\right)$ and the regression coefficient $\left(\boldsymbol{\beta}_{j}\right)$ are unknown parameters to be estimated by means of the maximum likelihood method.

The present study aims at exploring the impact of service quality of higher education institutions on students' satisfaction in Amhara Region. Ordinal logistic regression analysis with students' satisfaction as response variable and university, tangibility, assurance, reliability, responsiveness and empathy (all with three levels poor, fair and good) as potential predictors was used to analyze the data.

\section{RESULTS AND DISCUSSION}

\section{Descriptive Statistics}

Among all study participants, 364 (73.5\%) were male. Two hundred and eighty $(56.6 \%)$ of the students were originally from rural and the rest 210 $(42.4 \%)$ were from urban areas of the country. The majority of the students $321(64.8 \%)$ were from the Amhara region followed by Oromia 59 (11.9\%). From the point of view of religion, 81 percent of the students in the sample were Orthodox followed by Protestant 46 (9.3\%) (Table 1).

Table 2 displays distribution of students' satisfaction and service quality dimensions.

Table 1.Demographic Information

\begin{tabular}{|c|c|c|c|}
\hline Variables & & Frequency & Percent \\
\hline \multirow{3}{*}{ Sex } & Female & 130 & 26.3 \\
\hline & Male & 364 & 73.5 \\
\hline & Missing & 1 & 0.2 \\
\hline \multirow{3}{*}{ Area } & Rural & 280 & 56.6 \\
\hline & Urban & 210 & 42.4 \\
\hline & Missing & 5 & 0.1 \\
\hline \multirow{9}{*}{ Region } & Tigray & 33 & 6.7 \\
\hline & Amhara & 321 & 64.8 \\
\hline & Oromia & 59 & 11.9 \\
\hline & Benishangul & 2 & 0.4 \\
\hline & Gambela & 4 & 0.8 \\
\hline & Debub & 33 & 6.7 \\
\hline & Harer & 3 & 0.6 \\
\hline & AA and Dire Dewa & 39 & 7.9 \\
\hline & Missing & 1 & 0.2 \\
\hline \multirow{4}{*}{ Religion } & Orthodox & 401 & 81.0 \\
\hline & Muslim & 37 & 7.5 \\
\hline & Protestant & 46 & 9.3 \\
\hline & other & 11 & 2.2 \\
\hline
\end{tabular}


As shown in the table most of the students 357 (72.1\%) were satisfied, 108 (21.8\%) of them were neutral and the rest $6.8 \%$ were dissatisfied with their university. Nearly half $(49.3 \%)$ of sampled students were rated "Good" on tangibility while only $40(8.1 \%)$ of them rated the tangibility as "Poor". This indicates that only $8 \%$ of the students felt that the appearance of physical facilities, qualified personnel, well equipped laboratories and communication material was much worse than the expected.

Reliability is the ability to perform the promised service dependably and accurately. Nearly $92 \%$ of the sampled students rated reliability as "Good" or "Fair". Only $42(8.5 \%)$ of them rated reliability as "Poor".
The other important service quality dimension is responsiveness, willingness to help customers and provide prompt service. Again the majority 453 $(91.5 \%)$ of the students in the sample reported that the universities' service provision is responsive. The two service quality dimensions where a relatively large proportion of students rated as "Poor" are empathy and assurance 78 (15.8\%) and 65 (13.1\%) respectively).

In general the results of this study indicated that most students felt that the overall service quality dimensions is much better than the expected whereas only a few students felt that the overall service quality dimensions is much worse than the expected.

Table 2. Descriptive statistics on students' satisfaction and service quality dimensions

\begin{tabular}{|c|c|c|c|}
\hline Variables & & Frequency & Percent \\
\hline \multirow{3}{*}{ Students' Satisfaction } & Dissatisfied & 30 & 6.1 \\
\hline & Neutral & 108 & 21.8 \\
\hline & Satisfied & 357 & 72.1 \\
\hline \multirow{3}{*}{ Tangibility } & Poor & 40 & 8.1 \\
\hline & Fair & 211 & 42.6 \\
\hline & Good & 244 & 49.3 \\
\hline \multirow{3}{*}{ Assurance } & Poor & 65 & 13.1 \\
\hline & Fair & 204 & 41.2 \\
\hline & Good & 226 & 45.7 \\
\hline \multirow{3}{*}{ Reliability } & Poor & 42 & 8.5 \\
\hline & Fair & 210 & 42.4 \\
\hline & Good & 243 & 49.1 \\
\hline \multirow{3}{*}{ Responsiveness } & Poor & 42 & 8.5 \\
\hline & Fair & 218 & 44.0 \\
\hline & Good & 235 & 47.5 \\
\hline \multirow{3}{*}{ Empathy } & Poor & 78 & 15.8 \\
\hline & Fair & 209 & 42.2 \\
\hline & Good & 208 & 42.0 \\
\hline
\end{tabular}


Chi-square Test of Association between Service Quality and Students' Satisfaction

A chi-square test for the association between students' satisfaction with demographic variables and the five dimensions of service quality was performed. Students' university is the only demographic variable that has association with service quality dimensions (reliability and responsiveness) and with students' level of satisfaction. Results showed that students' university was significantly associated with reliability of the services (chi-square value $=11.995$ and $p$-value $=0.017$ ) and responsiveness (chisquare value $=9.617$ and $p$-value $=0.047$ ), meaning that students in different universities have responded differently regarding the reliability and responsiveness of the services provided by their universities. However, students from different universities have more or less similar responses regarding tangibility assurance and empathy (Table $3)$.

A chi-square test for the association between students' satisfaction and the five dimensions of service quality was performed. Since expected cell counts were less than five for each predictor variables, the response variable, students' satisfaction was merged from five Likert scales in to three Likert scales to maintain the validity of the chi-square test.

Table 3. Test of association between Service Quality Dimensions and University

\begin{tabular}{|c|c|c|c|c|c|c|c|c|}
\hline \multirow{2}{*}{ Variables } & & & \multicolumn{3}{|c|}{ Students University } & \multicolumn{3}{|c|}{ Chi-square } \\
\hline & & & DBU & BDU & UOG & Value & df & p-value \\
\hline \multirow{3}{*}{ Tangibility } & Poor & Count $(\%)$ & $5(12.5)$ & $19(47.5)$ & $16(40.0)$ & & & \\
\hline & Fair & Count $(\%)$ & $39(18.5)$ & $82(38.9)$ & $90(42.7)$ & 7.345 & 4 & 0.119 \\
\hline & Good & Count (\%) & $63(25.8)$ & $79(32.4)$ & $102(41.8)$ & & & \\
\hline \multirow{3}{*}{ Assurance } & Poor & Count $(\%)$ & $19(29.2)$ & $26(40.0)$ & $20(30.8)$ & & & \\
\hline & Fair & Count $(\%)$ & $35(17.2)$ & $80(39.2)$ & $89(43.6)$ & 7.734 & 4 & 0.102 \\
\hline & Good & Count $(\%)$ & $53(23.5)$ & $74(32.7)$ & $99(43.8)$ & & & \\
\hline \multirow{3}{*}{ Reliability } & Poor & Count $(\%)$ & $14(33.3)$ & $17(40.5)$ & $11(26.2)$ & & & \\
\hline & Fair & Count $(\%)$ & $35(16.7)$ & $87(41.4)$ & $88(41.9)$ & 11.995 & 4 & 0.017 \\
\hline & Good & Count $(\%)$ & $58(23.9)$ & $76(31.3)$ & 109 (44.9) & & & \\
\hline \multirow{3}{*}{ Responsiveness } & Poor & Count $(\%)$ & $14(33.3)$ & $16(38.1)$ & $12(28.6)$ & & & \\
\hline & Fair & Count (\%) & $41(18.8)$ & $90(41.3)$ & $87(39.9)$ & 9.617 & 4 & 0.047 \\
\hline & Good & Count (\%) & $52(22.1)$ & $74(31.5)$ & 109 (46.4) & & & \\
\hline \multirow{3}{*}{ Empathy } & Poor & Count $(\%)$ & $12(15.4)$ & $38(48.7)$ & $28(35.9)$ & & & \\
\hline & Fair & Count (\%) & $45(21.5)$ & $79(37.8)$ & $85(40.7)$ & 8.917 & 4 & 0.063 \\
\hline & Good & Count (\%) & $50(24.0)$ & $63(30.3)$ & $95(45.7)$ & & & \\
\hline
\end{tabular}


Results showed that students' satisfaction was significantly associated with tangibility (chi-square value $=59.22$ and $p$-value $<0.0001$ ), assurance (chi-square value $=90.29$ and $p$-value $<0.0001$ ), reliability (chi-square value $=138.93$ and $p$-value $<$ 0.0001 ), responsiveness (chi-square value $=129.67$ and p-value $<0.0001$ ), and empathy (chi-square value $=69.73$ and $p$-value $<0.0001$ ), meaning that students in different universities have responded differently regarding all service quality (tangibility, assurance, reliability, responsiveness and empathy) of their satisfaction (Table 4).
The impact of service quality dimensions (tangibility, assurance, reliability, responsiveness, and empathy) on students' satisfaction was measured by Cramer's V which showed significant positive relationship. The strength of the association between students' satisfaction and responsiveness was significant $(0.728)$ by reliability (0.687), assurance (0.615). Whereas, the strength of the association between students' satisfaction and empathy was moderate $(\mathrm{r}=0.531)$ followed by tangibility $(\mathrm{r}=0.515)$. The results showed that the service quality dimensions

Table 4. Test of association between Service Quality Dimensions and Students' Satisfaction

\begin{tabular}{|c|c|c|c|c|c|c|c|c|}
\hline \multirow{2}{*}{ Variables } & & & \multicolumn{3}{|c|}{ Students' Satisfaction } & \multicolumn{2}{|c|}{ Chi-square test } & \multirow{2}{*}{$\mathbf{r}$} \\
\hline & & & Dissatisfied & Neutral & Satisfied & value (df) & P-value & \\
\hline \multirow{3}{*}{ Tangibility } & Poor & Count (Expected) & $9(2.4)$ & $17(8.7)$ & $14(28.8)$ & \multirow{3}{*}{$59.22(4)$} & \multirow{3}{*}{0.00} & \multirow{3}{*}{0.515} \\
\hline & Fair & Count (Expected) & $10(12.8)$ & $63(46)$ & $138(152.2$ & & & \\
\hline & Good & Count (Expected) & $11(14.8)$ & $28(53.2)$ & $205(176)$ & & & \\
\hline \multirow{3}{*}{ Assurance } & Poor & Count (Expected) & $12(3.9)$ & $30(14.2)$ & $23(46.9)$ & \multirow{3}{*}{$90.29(4)$} & \multirow{3}{*}{0.00} & \multirow{3}{*}{0.615} \\
\hline & Fair & Count (Expected) & $7(12.4)$ & $63(44.5)$ & $134(147.1)$ & & & \\
\hline & Good & Count (Expected) & $11(13.7)$ & $15(49.3)$ & $200(163)$ & & & \\
\hline \multirow{3}{*}{ Reliability } & Poor & Count (Expected) & $14(2.5)$ & $20(9.2)$ & $8(30.3)$ & \multirow{3}{*}{$\begin{array}{c}138.93 \\
(4)\end{array}$} & \multirow{3}{*}{0.00} & \multirow{3}{*}{0.687} \\
\hline & Fair & Count (Expected) & $5(12.7)$ & $72(45.8)$ & $133(151.5$ & & & \\
\hline & Good & Count (Expected) & $11(14.7)$ & $16(53)$ & $216(175.3)$ & & & \\
\hline \multirow{3}{*}{ Responsiveness } & Poor & Count (Expected) & $12(2.5)$ & $21(9.2)$ & $9(30.3)$ & \multirow{3}{*}{$\begin{array}{c}129.67 \\
(4)\end{array}$} & \multirow{3}{*}{0.00} & \multirow{3}{*}{0.728} \\
\hline & Fair & Count (Expected) & $9(13.2)$ & $75(47.6)$ & (134 (175.2) & & & \\
\hline & Good & Count (Expected) & $9(14.2)$ & $12(51.3)$ & $214(169.5)$ & & & \\
\hline \multirow{3}{*}{ Empathy } & Poor & Count (Expected) & $10(4.7)$ & $39(17)$ & $29(56.3)$ & \multirow{3}{*}{$69.73(4)$} & \multirow{3}{*}{0.00} & \multirow{3}{*}{0.531} \\
\hline & Fair & Count (Expected) & $9(12.7)$ & $50(45.6)$ & $150(150.7)$ & & & \\
\hline & Good & Count (Expected) & $11(12.6)$ & $19(45.4)$ & $150(357)$ & & & \\
\hline
\end{tabular}


(Tangibility, assurance, reliability, responsiveness and empathy) have a significant impact on students' satisfaction. The result of this study contradicted with Fitri and Abd Razak (2008) of SERVQUAL model which showed that empathy has only strongest impact on students' satisfaction; whereas assurance, tangibility, responsiveness and reliability has a moderate impact on students' satisfaction. This difference might be due to differences in data analysis methods on top of the socio economic set up (Table 4).

\section{Ordinal Logistic Regression Analysis}

Ordinal logistic regression analysis was used to identify whether service quality dimensions have significant impact on students' satisfaction. Looking at the model fit of the data there is a highly significant reduction in the chi-square statistics $(p<0.005)$ so the model is clearly a significant improvement over the baseline or intercept only model from 507.708 to 356.579 with degree of freedom 12 and p-value of less than 0.0001. Table 5 depicted the estimates, the standard error of estimates, the Wald test value, the degree of freedom, the p-value and the $95 \%$ confidence intervals for estimates using proportional odds ordinal logistic regression model. The table revealed that reliability, responsiveness and empathy were significantly related with students' satisfaction whereas students' university, tangibility, assurance and interaction of university with service quality dimensions were not significantly related with students' satisfaction.

The odds ratios and their 95\% confidence intervals for dissatisfied versus satisfied students were computed as $\bar{O} \bar{R}=e^{\beta}$ and $\mathrm{e}^{\mathrm{LB}}, \mathrm{e}^{\mathrm{UB}}$ (Hosmer and Lemeshow, 2000) and the results displayed in Table 6. The odds of dissatisfied versus satisfied students was $\exp (-0.934)=0.393$, $\exp (-0.937)=0.392, \quad \exp (-0.458)=0.633$ and $\exp (-0.567)=0.567$ students who felt that the reliability of the university is much worse than the expected, students who perceived that the responsiveness of the university is much worse than the expected, students who perceived that the responsiveness of the university is just as the expected and students who felt that empathy is much worse than the expected, respectively (Table 5).

The results of this study showed that the service quality greatly influences the students' satisfaction in multiple dimensions. Among service quality dimensions; reliability, responsiveness and empathy have significant impacts on students' satisfaction whereas university, tangibility and assurance were not. This result is supported by Soutar and McNiel (2003). This means that although all service quality dimensions are actually useful in explaining students' satisfaction, but that does not mean that all dimensions are significant. In this study, among service quality dimensions, reliability for poor rate was significantly associated with students' satisfaction. The result of the ordinal logistic regression model revealed that given other service quality measures constant, the estimated odds of student's satisfaction who felt that the reliability of university is much worse than the expected were 0.393 less like than the odds of students who felt reliability of university is much better the expected.

The result is consistent with Edstrom (2008). According to Edstrom reliability (course instructors' performance and their methodology of teaching) as the prime indicators in their educational development and successful completion of their studies because the higher the intellectual ability of the instructor the better 
Table 5. Results of Ordinal Logistic Regression Model Using Students' satisfaction as Response with Three Categories (Dissatisfied, Neutral and satisfied)

\begin{tabular}{|c|c|c|c|c|c|c|c|c|}
\hline \multicolumn{9}{|c|}{ Parameter Estimates } \\
\hline & & \multirow{2}{*}{ Estimate } & \multirow{2}{*}{ Std. Error } & \multirow{2}{*}{ Wald } & \multirow{2}{*}{$\mathrm{df}$} & \multirow{2}{*}{ Sig. } & \multicolumn{2}{|l|}{$95 \% \mathrm{CI}$} \\
\hline & & & & & & & LB & UB \\
\hline Students' & Dissatisfied = 1 & -2.585 & .184 & 197.039 & 1 & $.000^{*}$ & -2.946 & -2.224 \\
\hline \multirow{3}{*}{$\begin{array}{l}\text { Satisfaction } \\
\text { (Threshold) }\end{array}$} & Neutral $=2$ & -1.371 & .151 & 82.740 & 1 & $.000^{*}$ & -1.667 & -1.076 \\
\hline & Satisfied $=3$ (Ref.) & & & & & & & \\
\hline & $\mathrm{DBU}=1$ & 0.130 & .173 & .560 & 1 & .454 & -.210 & .470 \\
\hline \multirow[t]{3}{*}{ University } & $\mathrm{BDU}=2$ & -0.043 & .141 & .094 & 1 & .759 & -.319 & .233 \\
\hline & $\mathrm{UOG}=3$ (Ref.) & & & & 0 & & & \\
\hline & Poor=1 & -0.320 & .239 & 1.800 & 1 & .180 & -.788 & .148 \\
\hline \multirow[t]{3}{*}{ Tangibility } & Fair $=2$ & -0.036 & .146 & .060 & 1 & .806 & -.323 & .251 \\
\hline & Good=3 (Ref.) & & & & & & & \\
\hline & Poor $=1$ & -0.236 & .244 & .929 & 1 & .335 & -.715 & .244 \\
\hline \multirow[t]{3}{*}{ Assurance } & Fair $=2$ & -0.112 & .181 & .385 & 1 & .535 & -.467 & .242 \\
\hline & Good=3 (Ref.) & & & & & & & \\
\hline & Poor $=1$ & -0.934 & .276 & 11.414 & 1 & $.001^{*}$ & -1.476 & -.392 \\
\hline \multirow[t]{3}{*}{ Reliability } & Fair $=2$ & -0.099 & .180 & .306 & 1 & .580 & -.452 & .253 \\
\hline & Good=3 (Ref.) & & & & & & & \\
\hline & Poor $=1$ & -0.937 & .294 & 10.184 & 1 & $.001^{*}$ & -1.512 & -.361 \\
\hline \multirow[t]{3}{*}{ Responsiveness } & Fair $=2$ & -0.458 & .194 & 5.569 & 1 & $.018^{*}$ & -.838 & -.078 \\
\hline & Good=3 (Ref.) & & & & & & & \\
\hline & Poor=1 & -0.567 & .203 & 7.799 & 1 & $.005^{*}$ & -.965 & -.169 \\
\hline \multirow[t]{2}{*}{ Empathy } & Fair $=2$ & -0.174 & .162 & 1.161 & 1 & .281 & -.491 & .143 \\
\hline & Good=3 (Ref.) & & & & & & & \\
\hline
\end{tabular}

will be the students' evaluation and consequently the higher the reliability will be on the teaching staffs. Similarly, Elliot and Shin (2002) stated that reliability (the teachers who teach with punctuality, accuracy, reasonability and logical approach in a student friendly manner) was more popular. Teachers' ability, excellence, coordination and reasonability greatly influence students' class performance and increase students' satisfaction.

The second service quality dimensions that has significant contribution towards students' satisfaction was responsiveness with the rates poor and fair. This means that students who perceived responsiveness of the university is much worse than the expected and just as the expected were 0.392 and 0.633 respectively less like the odds of students who perceived responsiveness of university is much better than the expected. This result is consistent with a previous study by Risch and Kleine (2000). This result indicated 
Table 6. The odds of dissatisfied versus satisfied for students' satisfaction at their University

\begin{tabular}{|c|c|c|c|c|c|c|}
\hline \multicolumn{7}{|c|}{ Parameter Estimates, Odds Ratio and $95 \%$ CI for OR } \\
\hline & & \multirow{2}{*}{ Estimate } & \multirow{2}{*}{ Wald } & \multirow{2}{*}{$\bar{O} \bar{R}=e^{\beta}$} & \multicolumn{2}{|c|}{ OR 95\% CI } \\
\hline & & & & & Lower & Upper \\
\hline Students' & Constant1 & -2.585 & 197.039 & - & - & - \\
\hline \multirow[t]{2}{*}{ Satisfaction } & Constant 2 & -1.371 & 82.740 & - & - & - \\
\hline & $\mathrm{DBU}=1$ & 0.130 & .560 & 1.139 & 0.811 & 1.600 \\
\hline \multirow[t]{3}{*}{ University } & $\mathrm{BDU}=2$ & -0.043 & .094 & 0.958 & 0.727 & 1.262 \\
\hline & $\mathrm{UOG}=3$ (Ref.) & & & - & - & - \\
\hline & Poor $=1$ & -0.320 & 1.800 & 0.726 & 0.455 & 1.160 \\
\hline \multirow[t]{3}{*}{ Tangibility } & Fair $=2$ & -0.036 & .060 & 0.965 & 0.724 & 1.285 \\
\hline & Good=3 (Ref.) & & & - & - & - \\
\hline & Poor $=1$ & -0.236 & .929 & 0.790 & 0.489 & 1.276 \\
\hline \multirow[t]{3}{*}{ Assurance } & Fair $=2$ & -0.112 & .385 & 0.894 & 0.627 & 1.274 \\
\hline & Good=3 (Ref.) & & & - & - & - \\
\hline & Poor $=1$ & -0.934 & 11.414 & 0.393 & 0.229 & 0.676 \\
\hline \multirow[t]{3}{*}{ Reliability } & Fair $=2$ & -0.099 & .306 & 0.906 & 0.636 & 1.288 \\
\hline & Good=3 (Ref.) & & & - & - & - \\
\hline & Poor $=1$ & -0.937 & 10.184 & 0.392 & 0.220 & 0.697 \\
\hline \multirow[t]{3}{*}{ Responsiveness } & Fair $=2$ & -0.458 & 5.569 & 0.633 & 0.433 & 0.925 \\
\hline & Good=3 (Ref.) & & & - & - & - \\
\hline & Poor $=1$ & -0.567 & 7.799 & 0.567 & 0.381 & 0.845 \\
\hline \multirow[t]{2}{*}{ Empathy } & Fair $=2$ & -0.174 & 1.161 & 0.840 & 0.612 & 1.154 \\
\hline & Good $=3$ (Ref.) & & & - & - & - \\
\hline
\end{tabular}

that students will be more motivated and good performers if their institution holds essential educational facilities with affective staff of teaching and training (responsiveness). The teachers' performance in the class and outside the class is a significant feature of enhancing students' satisfaction.

The third service quality dimensions that has significant contribution towards students' satisfaction was empathy. Students who perceived that empathy of the university is much worse than the expected were 0.567 less like the odds of students who perceived empathy of the university is much better than expected. The study, confirmed that empathy plays a crucial and an influential role toward satisfaction because "being able to communicate care and understanding through the interpersonal skills of the staff and studentfriendly policies and procedures" enhances students' satisfaction. O'Neill and Palmer (2004) said empathy is a dimension that is significant with students' satisfaction, because according to Clewes (2003) the process of teaching and learning is actually the central part to students' evaluation of service quality. It could have an effect toward students' satisfaction. 


\section{CONCLUSIONS AND \\ RECOMMENDATIONS}

The findings of the study revealed that most students felt that satisfaction and over all service quality was much better than what was expected at their University. The results of Chi-square test showed that there was significant difference within students' satisfaction, reliability, and responsiveness and universities. The results revealed further that there was a significant association between service quality dimensions and students' satisfaction. Among service quality dimensions, responsiveness has significant impact on students' satisfaction. The results of ordinal logistic regression analysis also showed that reliability, responsiveness and empathy were having significant effects on students' satisfaction whereas University, tangibility and assurance were having no significant effects on students' satisfaction.

Tangibility is the dimension that was not associated with the students' satisfaction. It means that the physical appearance of the educational institution is not a matter of consideration for students instead the essence of students' satisfaction lies in the quality of teaching and learning environment of institution as students demand the well qualified, learned and experienced faculty for their academic and professional development. The students wanted to be taught by those teachers whose knowledge, expertise, liberality and reasonability up to the mark. The teaching methodologies and understanding with course and tasks with a friendly attitude of teaching were the key factors affecting the academic environment of an institution. Therefore, as now a day recruiting well qualified teachers become negligent and hence Universities should be stringent in controlling quality while recruiting the teachers and make them accountable.

\section{LIMITATIONS}

One of the limitations of this study was that the scope was limited to only first degree students at three government owned universities. For more complete results privately owned higher education institutions that offer courses for the bachelor and masters degrees could have been included. Another dimension for future studies could be a comparative study on students' satisfaction in service quality at government versus privately owned higher education institutions.

\section{ACKNOWLEDGMENTS}

The study was sponsored by the College of Science, Bahir Dar University, Ethiopia. We thank the college for the support. The authors would also like to express their gratitude's to data collectors and respondents who participated in this study.

\section{REFERENCES}

Anderson, E., Fornell, C and Lehman, D. (1994). Customer satisfaction, market share, and profitability: findings from Sweden. Journal of Marketing 58: 53-66.

Barnes, B. (2005). Analyzing service quality: the case of post-graduate Chinese students. Leeds University Business School 2.

Berry, L.L., Zeithaml, V A and Parasuraman, A. (1990). Five imperatives for improving service quality. Sloan Management Review 31 (4): $29-38$

Clewes, D. (2003). A Student-centered conceptual model of service quality in higher education. Quality in Higher Education 9 (1): 69-85. 
Cochran W.G. (1977). Applied logistic regression. John Wiley and Sons Inc., New York.

Cronin, J and Talyor, S. (1994). SERVPERF versus SERVQUAL: reconciling performance -based and perceptions -minus-expectations measurement of service quality. Journal of Marketing 58: 125-131.

Demeke Lakew. (2014). Students' satisfaction with service quality in higher education institutions: an empirical study in university of Gondar. Journal of Education and Practice 23 (5): 24-32.

DeShields, Jr O.W., Kara, A and Kaynak, E. (2005). Determinants of business student satisfaction and retention in higher education: applying Herzberg's two factor theory. International Journal of Education Management 19 (2): 128-139.

Edstrom, K. (2008). Doing course evaluations as if learning matters most. Higher Education Research and Development 27: 95-106.

Elliot, K. M and Shin, D. (2002). Student satisfaction: an alternative approach to assessing this important concept. Journal of Higher Education Policy and Management 24 (2): 197-209.

Fitri, H. A. H., Ilias, A., Abd Rehman, R and Abd Razak, M. Z. (2008). Service quality and student satisfaction: a case study at private higher education institutions. International Business Research 1(03): 163-175.

Gallifa, J and Batalle, P. (2010). Student perceptions of service quality in a multicampus higher education system in Spain. Quality Assurance in Education 18 (2): 156170 .
Hair, JF., Black, WC., Barry JB., Anderson RE and Tatham RL. (2006). Multivariate data analysis. $6^{\text {th }}$. Pearson, Prentice Hall, New Jersey.

Hosmer, D.W and Lemeshow, S. (2000). Applied logistic regression. $2^{\text {nd }}$ ed., New York: John Wiley and Sons, Inc., pp 288-305.

Khan, M.M., Nawa, M. M., Ahme, I and Naqv, I, H. (2011). Teaching Quality in Higher Education: what do we need to improve. Interdisciplinary Journal of Research in Business 1(4): 37-42.

Kotler, P and Clarke, R.N. (1987). Marketing for health care organizations. Englewood Cliffs, NJ: Prentice-Hall.

Murray (2001). What do MFI customers Value? A comparative analysis from three continents. the $\mathrm{IV}^{\text {th }}$ Interamerican Conference on Microenterprise, Dominican Republic, November $14^{\text {th }}$ to $16^{\text {th }}$.

O’Neill, M. A and Palmer, A. (2004). Importanceperformance analysis: a useful tool for directing continuous quality improvement in higher education. Quality Assurance in Education 12(1): 39-52.

Parasuraman, A., Zeithaml, V. A and Berry, L.L (1988), SERVQUAL: a multiple-item scale for measuring consumer perceptions of service quality. Journal of Retailing 64 (1): 12-40.

Parasuraman, A., Zeithaml, V. A and Berry, L. L. (1996). The behavioral consequences of service quality. Journal of Marketing 60 (2): 31-46.

Risch, R. A and Kleine, S .S (2000). Customer participation in service production and delivery. In Handbook of Services Marketing and Management. Eds. Teresa A. Swartz and Dawn Iacobucci. Thousand Oaks: Sage: 111125. 
Sekaran, U. (1992). Research method for business: A skill building approach. New York: John Wiley and Sons Inc.

Soutar, G and McNiel, M. (1996). Measuring service quality in a tertiary institution. Journal of Educational Administration 34 (1): 72-82.

Zammuto, R. F., Keaveney, S. M and O'connor, E. J. (1996). Rethinking student services: assessing and improving service quality. Journal of Marketing in Higher Education 7(1):45- 69.

Zeithaml, V. A. (1987). Defining and relating price, perceived quality and perceived value. Cambridge, MA: Marketing Science Institute.

Zeithaml, V.A. (2000). Service quality, profitability, and the economic worth of customers: what we know and what we need to learn. Journal of the Academy of Marketing Science 28 (1): 67-85. 